\title{
On the structural variations of $\mathrm{Ru}(\mathrm{II})$ complexes for dye-sensitized solar cells
}

\author{
Ying-Chan Hsu ${ }^{\mathrm{a}}$, Hegen Zheng ${ }^{\mathrm{b}}$, Jiann T'suen Lin ${ }^{\mathrm{c}}$, \\ Kuo-Chuan $\mathrm{Ho}^{\mathrm{a}, \mathrm{d}, *}$ \\ a Department of Chemical Engineering, National Taiwan University, Taipei 106, Taiwan \\ ${ }^{\mathrm{b}}$ State Key Laboratory of Coordination Chemistry, Nanjing University, Nanjing 210093, PR China \\ ${ }^{\mathrm{c}}$ Institute of Chemistry, Academia Sinica, Nankang, Taipei 115, Taiwan \\ ${ }^{\mathrm{d}}$ Institute of Polymer Science and Engineering, National Taiwan University, \\ Room 110A, 1, Sec. 4, Roosevelt Road, Taipei 10617, Taiwan
}

Received 15 May 2004; received in revised form 12 July 2004; accepted 15 July 2004 Available online 23 November 2004

\begin{abstract}
Ruthenium(II) complexes with new phenanthrenyl ligand (TAPNB) have been synthesized and examined. The spectroscopic and electrochemical measurements showed that the excited states of those complexes matched the conduction band of titanium dioxide. The overall power conversion efficiencies of the solar cells utilized these new complexes as sensitizers for $\mathrm{TiO}_{2}$ films were less than that of $\mathrm{N} 3$-sensitized cell. Although the open-circuit voltage was similar to that of N3-sensitized cell, the short-circuit current was $\sim$ one order lower. Such outcome may be attributed to the less amount of dyes adsorbed due to the steric congestion of the complex. When NCS ligand was replaced by pyridyl ligand, the energy of metal-to-ligand charge transfer $(\mathrm{Ru}(\mathrm{II}) \rightarrow \mathrm{TAPNB})$ increased and resulted in blue shift of the absorption band. Anchoring of carboxylic acid at the surface of $\mathrm{TiO}_{2}$ slightly lowered the energy of $\mathrm{Ru}(\mathrm{II}) \rightarrow$ TAPNB charge transfer band. As carboxylic acid anchor was replaced by acetyl ester, the weaker interaction between the semiconductor and the ligand led to diminishing amount of the complex adsorbed and less photocurrent was detected.
\end{abstract}

(C) 2004 Elsevier B.V. All rights reserved.

Keywords: Dye-sensitized solar cell; Ruthenium dye; Phenanthrenyl ligand; Titanium dioxide

\footnotetext{
*Corresponding author. Tel.: + 886223660739 ; fax: + 886223623040 .

E-mail address: kcho@ntu.edu.tw (K.-C. Ho).
} 


\section{Introduction}

Dye sensitization of large band gap semiconductors has been investigated for many years [1-3]. An efficiency up to $10 \%$ [4,5] has been achieved on dye-sensitized solar cells (DSSCs) based on bis(bipyridyl) ruthenium complexes-coated $\mathrm{TiO}_{2}$. Recently, several organic dyes possessing intense charge transfer character were found to be promising sensitizers for solar cells [6-8]. Such dipolar type compounds can be effectively tuned to absorb in the longer wavelength region via incorporation of a methine unit in the conjugation spacer. However, oligomethine moiety is not particularly stable in general. Low-band gap conjugated oligomers have been demonstrated to be alternate for photovoltaic cells [9,10]. Among these, cis$\mathrm{Ru}(\mathrm{NCS})_{2}$ (dcbpy) (dcbpy $=2,2^{\prime}$-bipyridyl-4,4'-dicarboxylate) and $\mathrm{Ru}(\mathrm{NCS})_{3}$ (terpy) $\left(\right.$ terpy $=2,2^{\prime}, 2^{\prime \prime}$-terpyridyl-4, $4^{\prime}, 4^{\prime \prime}$-tricarboxylate) appear to be most promising [11-14].

Ideal dyes should show increased absorption in the red region and retain a high photopotential and a quantitative incident monochromatic photo-to-current
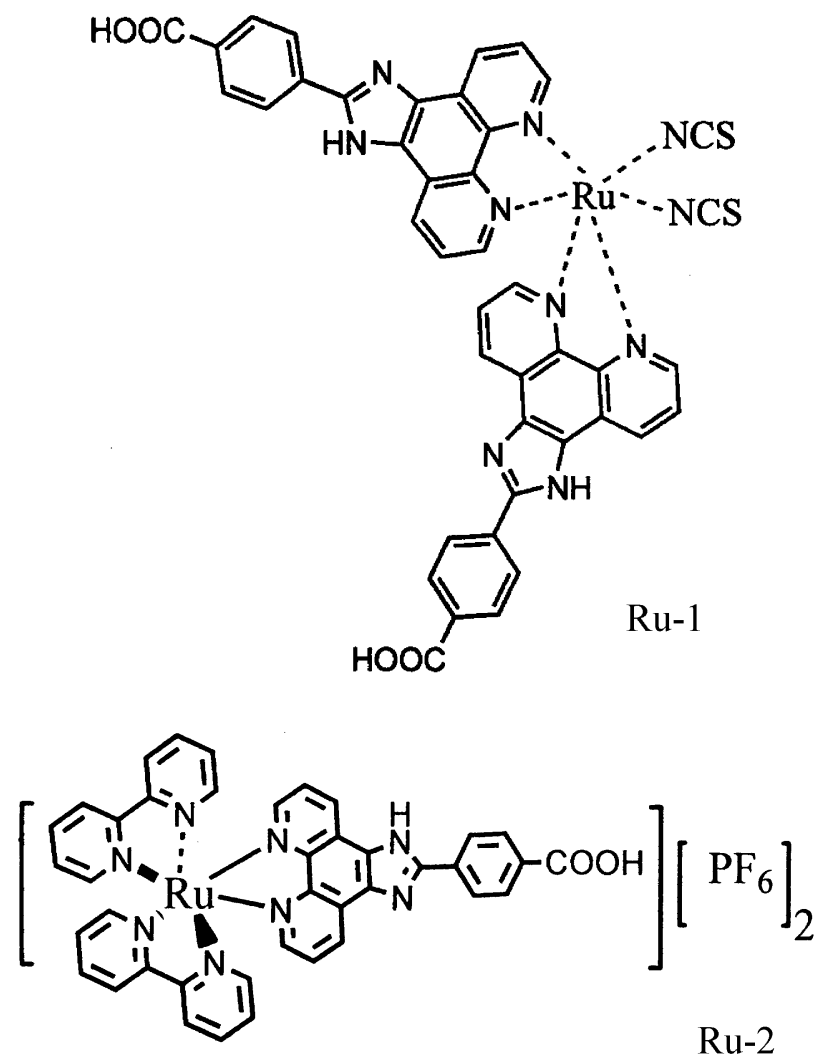

Scheme 1. Molecular structures of Ru-1 and Ru-2 complexes. 
conversion efficiency (IPCE) at shorter wavelength in the device. Approaches toward this aim include: (1) use of ligands with a lower $\pi^{*}$ level than $4,4^{\prime}$-dicarboxy-2,2'bipyridine; (2) raising the energy of the ruthenium $t_{2 g}$ orbitals; (3) increasing the metal-to-ligand charge transfer (MLCT) coefficient $[15,16]$. Appropriate elongation of the conjugation length or incorporation of electron-withdrawing segments to terpyridine (or bipyridine) ligands is expected to lower the $\pi^{*}$ energy level of the terpyridines. Consequently, metal terpyridine complexes may have a lower MLCT energy. On the other hand, ruthenium ground state tuning may be approached by using a better electron-donating ligand such as benzimidazole [17]. Therefore, dedicate balance of electronic factors among different ligands is important.

In this study, we have synthesized new phenanthrenyl ligand, 4- $(1 \mathrm{H}-1,3,7,8$ tetraaza-cyclopenta[1]phenanthren-2-yl)-benzoic acid (abbreviated as TAPNB), possessing elongated conjugation for lower $\pi^{*}$ orbital energy level. Ruthenium complexes containing the new ligand were synthesized and subjected to photovoltaic studies. Scheme 1 shows the structural variations of two dyes: (1) Ru-1 $\left(\mathrm{Ru}(\mathrm{TAPNB})_{2}(\mathrm{NCS})_{2}\right)$ with two SCN ligands and two $-\mathrm{COOH}$ anchors; (2) Ru-2 $\left(\left[\mathrm{Ru}(\mathrm{TAPNB})(\text { bipy })_{2}\right]\left[\mathrm{PF}_{6}\right]_{2}\right)$ with two pyridine ligands and one $-\mathrm{COOH}$ anchor. A comparison with the ruthenium complex containing 4,4'-dicarboxy-2,2'-bipyridine will be discussed.

\section{Experimental}

\subsection{Chemicals and substrate}

All the chemicals were ACS reagent grade and not further purified before using. Fluoride-doped tin oxide (FTO) conducting glass substrates, serving as the optically transparent electrodes (OTEs), were obtained from a local supplier (Sinonar Corporation, Hsinchu, Taiwan), and the sheet resistance was ca. $30 \Omega /$ sq.

\subsection{Preparation and characterization of the $R u$ complexes}

\subsubsection{Phenanthrenyl ligands}

TAPNB and 4-(1H-1,3,7,8-tetraaza-cyclopenta[1]phenanthren-2-yl)- benzoic acid methyl ester (abbreviated as TAPNBE) were prepared by a similar procedure. Only the synthesis of TAPNB will be described in detail.

TAPNB: A mixture of aldehyde $(3.5 \mathrm{mmol}), 1,10$-phenanthroline-5,6-dione $(2.5 \mathrm{mmol})$, ammonium acetate $(50 \mathrm{mmol})$ and glacial acetic acid $(15 \mathrm{ml})$ was refluxed for about $6 \mathrm{~h}$, then cooled to room temperature and diluted with water (ca. $25 \mathrm{ml}$ ). Yellow precipitates were collected and washed with water. The crude products were purified by recrystillization with methanol to produce TAPNB as yellow-white solids $(720 \mathrm{mg}, 85 \%)$. The proton NMR spectrum was recorded in $\mathrm{d}_{6^{-}}$ DMSO on a $300 \mathrm{MHz}$ NMR spectrometer (Bruker AC300). ${ }^{1} \mathrm{H}$ NMR $(\delta$, ppm, TMS): 7.84-7.94 (m, 2H, phen), 8.17 (d, $\left.J=8.44,2 \mathrm{H}, \mathrm{C}_{6} \mathrm{H}_{4}\right), 8.40(\mathrm{~d}, J=8.44,2 \mathrm{H}$, $\left.\mathrm{C}_{6} \mathrm{H}_{4}\right), 8.91-8.94$ (m, 2H, phen), 9.03-9.05 (m, 2H, phen), 13.94 (s, 1H, COOH). 
Mass spectra (EI) were recorded on a VG70-250S mass spectrometer. FAB MS $(m / e): 341.1(\mathrm{M}+\mathrm{H})$.

TAPNBE: Yellow solid. Yield $=73 \% .{ }^{1} \mathrm{H}$ NMR $\left(\mathrm{d}_{6}\right.$-DMSO): $\delta 3.9\left(\mathrm{~s}, 3 \mathrm{H}, \mathrm{CH}_{3}\right)$, 7.81-7.84 (m, 2H, phen), 8.19 (d, $\left.J=8.18,2 \mathrm{H}, \mathrm{C}_{6} \mathrm{H}_{4}\right), 8.43\left(\mathrm{~d}, J=8.15,2 \mathrm{H}, \mathrm{C}_{6} \mathrm{H}_{4}\right)$, 8.92-8.95 (m, 2H, phen), 9.03-9.05(m, 2H, phen). FAB MS $(m / e): 355.1(\mathrm{M}+\mathrm{H})$.

\subsubsection{Preparation of ( $\left.\mathrm{Ru}(\mathrm{TAPNB})_{2}(\mathrm{NCS})_{2}\right)$ ( $\mathrm{Ru}$-1)}

$\mathrm{RuCl}_{3} \cdot 2 \mathrm{H}_{2} \mathrm{O}(262 \mathrm{mg}, 1.0 \mathrm{mmol})$, TAPNB $(681 \mathrm{mg}, 2.0 \mathrm{mmol})$ and $\mathrm{LiCl}(1 / 15$ mmol, $2.0 \mathrm{mg}$ ) were added to dimethylformamide (DMF) $(60 \mathrm{ml})$. The mixture was refluxed for $3 \mathrm{~h}$, then cooled to room temperature, and DMF was evaporated in $\mathrm{N}_{2}$. The residue was added acetone and solid formed was collected and dried for next step reaction. TAPNB $\mathrm{RuCl}_{2}(768 \mathrm{mg}, 0.9 \mathrm{mmol})$ and $\mathrm{KNCS}(1.75 \mathrm{~g}, 18 \mathrm{mmol})$ were added to DMF $(80 \mathrm{ml})$, and the solution was refluxed for $6 \mathrm{~h}$. The solvent DMF was evaporated under vacuum, and the resulting solid was collected in a sintered glass, washed with methanol and ether. Brownish product was obtained in $65 \%$ yield after purification with column chromatography (DMF:EtOH $=1: 20$ as eluent). ${ }^{1} \mathrm{H}$ NMR ( $\delta$, ppm, TMS): 7.88-7.92 (m, 2H, phen), $8.15\left(\mathrm{~d}, J=8.40,2 \mathrm{H}, \mathrm{C}_{6} \mathrm{H}_{4}\right), 8.42(\mathrm{~d}$, $\left.J=8.40,2 \mathrm{H}, \mathrm{C}_{6} \mathrm{H}_{4}\right), 8.95-8.99$ (m, phen, 2H), 9.06-9.10 (m, 2H, phen), 14.22 (s, $1 \mathrm{H}$, $\mathrm{COOH})$. FAB MS (m/e): 898.1. Anal. Calc. for $\mathrm{C}_{42} \mathrm{H}_{24} \mathrm{~N}_{10} \mathrm{O}_{4} \mathrm{RuS}_{2}$ : C, 56.18; H, 2.69; N, 15.60. Found: C, 57.07; H, 2.95; N, 15.22.

\subsubsection{Preparation of $\left(\mathrm{Ru}(\mathrm{TAPNBE})_{2}(\mathrm{NCS})_{2}\right)(\mathrm{Ru}-12)$}

The complex Ru-12 was synthesized by a similar procedure as described for Ru-1 except that TAPNBE was used instead of TAPNB. Brownish product was obtained in $60 \%$ yield after purification with column chromatography (DMF:EtOH $=1: 20$ as eluent). ${ }^{1} \mathrm{H}$ NMR (d ${ }_{6}$-DMSO): $\delta 3.9\left(\mathrm{~s}, 3 \mathrm{H}, \mathrm{CH}_{3}\right), 7.68-7.76(\mathrm{~m}, 2 \mathrm{H}$, phen), 8.11 (d, $\left.J=8.18,2 \mathrm{H}, \mathrm{C}_{6} \mathrm{H}_{4}\right), 8.35\left(\mathrm{~d}, J=8.15,2 \mathrm{H}, \mathrm{C}_{6} \mathrm{H}_{4}\right), 8.93-9.02(\mathrm{~m}, 2 \mathrm{H}$, phen), 9.24-9.34 (m, 2H, phen). FAB MS (m/e): 926.1. Anal. Calc. for $\mathrm{C}_{44} \mathrm{H}_{28} \mathrm{~N}_{10} \mathrm{O}_{4} \mathrm{RuS}_{2}$ : C, 57.07; H, 3.05; N, 15.13. Found: C, 57.87; H, 3.45; N, 14.75.

\subsubsection{Preparation of $\left[R u(T A P N B)(\text { bipy })_{2}\right]\left[P F_{6}\right]_{2}(R u-2)$}

To a stirred, deaerated solution of ligands TAPNB $(0.5 \mathrm{mmol})$ in ethanol $(20 \mathrm{ml})$ was added $\left[\mathrm{Ru}(\mathrm{bpy})_{2} \mathrm{Cl}_{2}\right] \cdot 2 \mathrm{H}_{2} \mathrm{O}(260 \mathrm{mg}, 0.5 \mathrm{mmol})$. The reaction mixture was heated under reflux for $6 \mathrm{~h}$ in an argon atmosphere. After cooling to room temperature, an aqueous solution of $\mathrm{NH}_{4} \mathrm{PF}_{6}$ was added until no further precipitate was formed. After the suspension was stored for $2 \mathrm{~h}$ at $0{ }^{\circ} \mathrm{C}$, the precipitate was filtered, washed successively with $\mathrm{H}_{2} \mathrm{O}(10 \mathrm{ml})$, ethanol $(10 \mathrm{ml})$ and diethyl ether $(20 \mathrm{ml})$ to furnish the metal complexes as analytically pure orange to red solids in $78 \%$ yield $(390 \mathrm{mg}) .{ }^{1} \mathrm{H}$ NMR $\left(\mathrm{d}_{6}\right.$-DMSO): $\delta 7.34(\mathrm{t}, J=6.7,2 \mathrm{H}$, bpy), 7.57-7.62 (m, 4H, bpy), 7.84 (d, $J=5.4,2 \mathrm{H}$, bpy), 7.95 (m, 2H, phen), 8.07-8.12 (m, 4H, bpy), 8.19-8.23 (m, 4H, bpy, $\left.\mathrm{C}_{6} \mathrm{H}_{4}\right), 8.46\left(\mathrm{~d}, J=8.2,2 \mathrm{H}, \mathrm{C}_{6} \mathrm{H}_{4}\right), 8.83-8.89(\mathrm{~m}, 4 \mathrm{H}$, phen, bpy), 9.1-9.2 (m, 2H, phen), 14.8 (s, 1H, COOH). FAB MS (m/e): $753.3\left(\mathrm{M}-2 \mathrm{PF}_{6}\right)$. Elemental analyses were performed on a Perkin-Elmer $2400 \mathrm{CHN}$ analyzer. Anal. Calc. for $\mathrm{C}_{40} \mathrm{H}_{28} \mathrm{~F}_{12} \mathrm{~N}_{8} \mathrm{O}_{2} \mathrm{P}_{2} \mathrm{Ru}$ : C, 46.03; H, 2.70; N, 10.74. Found: C, 46.08; H, $2.75 ; \mathrm{N}, 11.03$. 


\subsubsection{Preparation of $\left[R u(T A P N B E)(\text { bipy })_{2}\right]\left[P F_{6}\right]_{2}(R u-22)$}

The complex Ru-22 was synthesized by a similar procedure as described for $\mathrm{Ru}-2$ except that TAPNBE was used instead of TAPNB. Red solid. Yield $=70 \%{ }^{1} \mathrm{H}$ NMR (d ${ }_{6}$-DMSO): $\delta 3.92\left(\mathrm{~s}, 3 \mathrm{H}, \mathrm{CH}_{3}\right), 7.32-7.36(\mathrm{~m}, 2 \mathrm{H}, \mathrm{bpy}), 7.57-7.63(\mathrm{~m}, 4 \mathrm{H}$, bpy), 7.83-7.84 (m, 2H, bpy), 7.90-7.98 (m, 2H, phen), 8.07-8.12 (m, 4H, bpy), 8.20-8.24 (m, 4H, bpy, $\left.\mathrm{C}_{6} \mathrm{H}_{4}\right), 8.52\left(\mathrm{~d}, J=8.13,2 \mathrm{H}, \mathrm{C}_{6} \mathrm{H}_{4}\right), 8.83-8.89(\mathrm{~m}, 4 \mathrm{H}$, phen, bpy), 9.10-9.28 (m, 2H, phen). FAB MS (m/e): 912.9 (M-PF 6$)$. Anal. Calc. for $\mathrm{C}_{41} \mathrm{H}_{30} \mathrm{~F}_{12} \mathrm{~N}_{8} \mathrm{O}_{2} \mathrm{P}_{2} \mathrm{Ru}: \mathrm{C}, 46.56 ; \mathrm{H}, 2.86 ; \mathrm{N}, 10.59$. Found: C, 46.12; H, 3.36; N, 10.27 .

\subsubsection{Spectroscopic and electrochemical studies}

Electronic absorption spectra were obtained on a Perkin-Elmer Lambda 9 spectrometer. Emission spectra were recorded by a Hitachi F-4500 fluorescence spectrometer. The details on the experimental set-up for fluorescence lifetime measurements have been described in the previous report [18]. Cyclic voltammetry experiments were performed with a BAS-100 electrochemical analyzer. All measurements were carried out at room temperature with a conventional threeelectrode configuration consisting of platinum working and auxiliary electrodes and a nonaqueous $\mathrm{Ag} / \mathrm{AgNO}_{3}$ reference electrode. All potentials are reported relative to $\mathrm{Ag} / \mathrm{AgNO}_{3}$ and are not corrected for the junction potential. $\mathrm{Fc}^{+} / \mathrm{Fc}$ was measured to be $0.22 \mathrm{~V}$ relative to $\mathrm{Ag} / \mathrm{AgNO}_{3}$. The details on the experimental set-up for electrochemical measurements have been described in the previous report [19].

\subsection{Preparation of the $\mathrm{TiO}_{2}$ thin film and dye adsorption}

The $\mathrm{TiO}_{2}$ thin film, serving as the photoanode in this work, was prepared through the general sol-gel method. The precursor solution was made according to the following procedure: $135 \mathrm{ml}$ of $0.1 \mathrm{M}$ nitric acid solution under vigorous stir was dropped with $22.5 \mathrm{ml}$ pure $\operatorname{Ti}\left(\mathrm{C}_{3} \mathrm{H}_{7} \mathrm{O}\right)_{4}$ slowly to form a mixture. After the hydrolysis, the mixture was heated at $85 \pm 5^{\circ} \mathrm{C}$ in a water bath and stirred vigorously for $12 \mathrm{~h}$ in order to achieve the peptization. When the mixture cooled down to room temperature, it was ultrasonically vibrated for $10 \mathrm{~min}$, and then $30 \mathrm{wt} \%$ of polyethylene glycol (molecular weight of 20000) was added in a proportion of the $\mathrm{TiO}_{2}$ weight. The precursor solution with an equivalent $\mathrm{TiO}_{2}$ concentration of ca. $4 \mathrm{wt} \%$ was thus obtained and ready for the subsequent dip-coating process.

During the dip-coating operation, a cleaned FTO glass substrate with a dimension of $4 \times 2 \mathrm{~cm}^{2}$ was half dipped into the solution. After $10 \mathrm{~min}$, the substrate was slowly drawn out with a speed of $6 \mathrm{~cm} / \mathrm{min}$. The dipping-drawing out procedure was performed ten times totally, and the substrate was maintained as vertically as possible. After exposing to air for $30 \mathrm{~min}$, the substrate coated with the precursor solution was dried at $50{ }^{\circ} \mathrm{C}$ for $15 \mathrm{~min}$. Then it was heated to $450{ }^{\circ} \mathrm{C}$ at a rate of $20^{\circ} \mathrm{C} \mathrm{min}^{-1}$ and then sintered at $450^{\circ} \mathrm{C}$ for $30 \mathrm{~min}$ to form the $\mathrm{TiO}_{2}$ thin film. The film was cooled down naturally to room temperature. The thickness of the $\mathrm{TiO}_{2}$ film was estimated as ca. $5 \mu \mathrm{m}$ from a side-view scanning electron microscopic (SEM, Hitachi, model S800) image and a profilometer (Sloan technology, Dektak 3030). 
The dye adsorption on the sintered $\mathrm{TiO}_{2}$ thin film was performed as follows: After heating the $\mathrm{TiO}_{2}$ thin film to $80^{\circ} \mathrm{C}$, the film was taken out from the oven and dipped into the solution containing $3 \times 10^{-4} \mathrm{M}$ dye sensitizers. The solvents used were dimethylformamide for $\mathrm{Ru}-1$ and $\mathrm{Ru}-12$, acetonitrile for $\mathrm{Ru}-2$ and $\mathrm{Ru}-22$, and ethanol for cis-di(thiocyanato)bis(2,2'-bipyridyl-4,4'-dicarboxylate)ruthenium(II) (N3, Solaronix) for at least $12 \mathrm{~h}$, respectively.

\subsection{Assembly and characterization of the DSSCS}

The dye-sensitized photoanode was rinsed with acetonitrile and dry. A platinized FTO with $1 \mu \mathrm{m}$-thick Pt by sputtering was used as a counter electrode and was controlled an active area of $1 \times 1 \mathrm{~cm}^{2}$ by adhered polyester tape $(3 \mathrm{M})$ with thickness of $60 \mu \mathrm{m}$. The photoanode was placed on top of the counter electrode and tightly clipping them together to form a cell. Electrolyte was then injected into the cell space through one of the two open holes present in the tape and then sealing the cell with the Torr Seal ${ }^{\circledR}$ cement (Varian, MA, USA). The electrolyte was composed of $0.5 \mathrm{M}$ tetrabutylammonium iodide (TBAI), 0.02 M lithium iodide (LiI), 0.05 M iodine $\left(\mathrm{I}_{2}\right)$, and $0.5 \mathrm{M}$ 4-tert-butylpyridine that was dissolved in acetonitrile.

The photoelectrochemical characterizations on the solar cells were carried out using an AM 1.5 simulated light radiation. The light source was emitted from a $450 \mathrm{~W}$ Xe lamp (Oriel, \#6266) equipped with a water-based IR filter and AM 1.5 filter (Oriel, \#81075). Light intensity attenuated by neutral density filter (Optosigma, $\# 078-0360$ ) at the measuring (cell) position was estimated to be ca. $10 \mathrm{~mW} \mathrm{~cm}^{-2}$ upon the reading from a radiant power meter (Oriel, \#70260) connected to a thermopile probe (Oriel, \#70263). Photoelectrochemical characteristics of the DSSCs, including their on-off responses of open-circuit voltages and photocurrent-voltage curves, were recorded through the potentiostat/galvanostat.

\section{Results and discussion}

\subsection{Spectroscopic and electrochemical properties of Ru complexes}

Figs. 1, 2 and 3 show the normalized absorption spectra of Ru-1, Ru-2 and N3 on $\mathrm{TiO}_{2}$ films and in organic solutions, respectively. The spectral difference between adsorbed complex on $\mathrm{TiO}_{2}$ film and dissolved molecule in solution is resulted from $\pi^{*}$ bond formed by $\mathrm{Ti} 3 \mathrm{~d}$ orbital and $\pi^{*}$ orbital of ligand electronic coupling. A larger red shift was observed in $\mathrm{Ru}-2$ containing bipyridine. The same phenomenon was reported and was suggested to be due to increasing delocalization of electrons from $\mathrm{Ru}$ complex containing pyridyl ligand to $\mathrm{TiO}_{2}$ [20]. Absorption and electrochemical data of $\mathrm{Ru}$ complexes were listed in Table 1. From the oxidation potential of $\mathrm{Ru}^{2+}, E_{\mathrm{ox}}^{0^{\prime}}$, the highest occupied molecular orbital (HOMO) of each complex was calculated. The presence of electron-withdrawing bipyridine likely lowers the electron density of the ruthenium center which will lower the energy of $\mathrm{Ru}$ $\mathrm{t}_{2 \mathrm{~g}}$ orbital and increase the transition energy from the $\mathrm{Ru}$ center to TAPNB. 


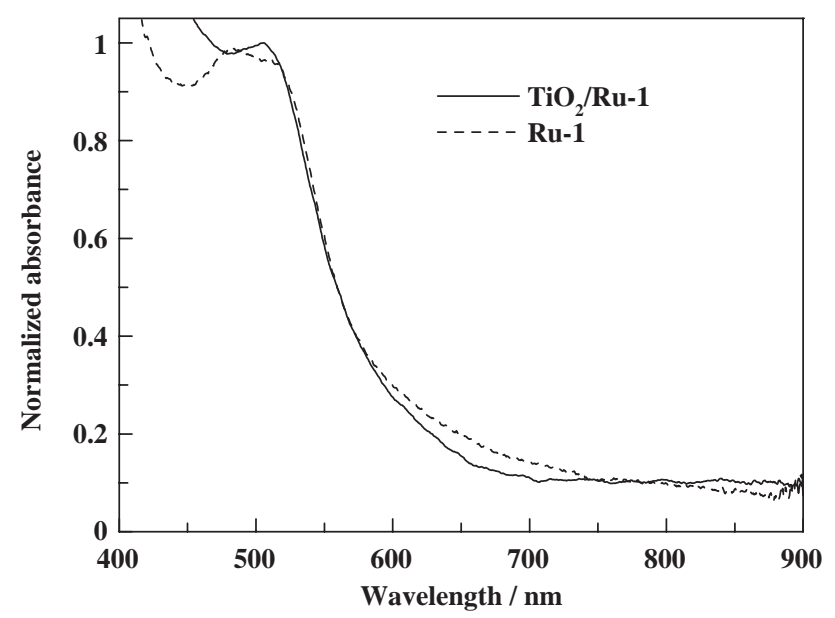

Fig. 1. Normalized absorption spectra of $\mathrm{Ru}-1$ on $\mathrm{TiO}_{2}$ film (solid line) and in DMF solution (dash line).

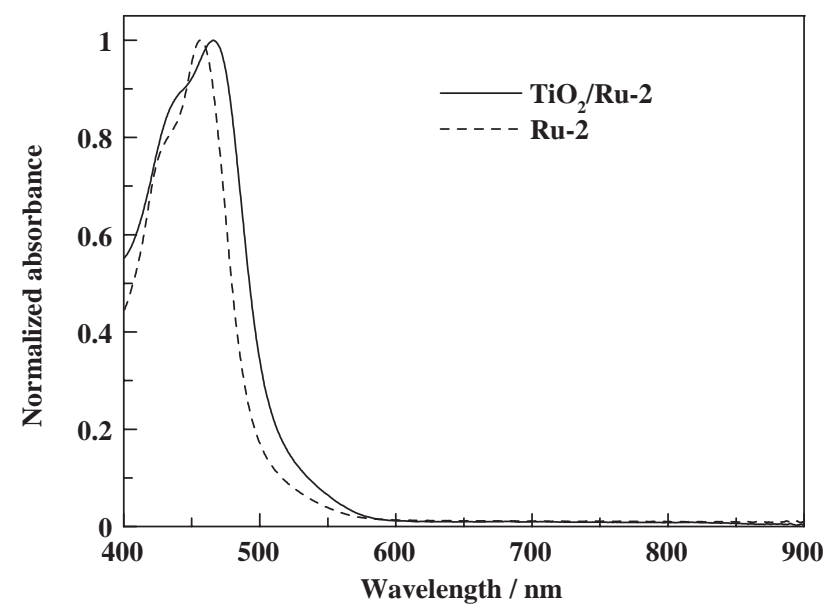

Fig. 2. Normalized absorption spectra of $\mathrm{Ru}-2$ on $\mathrm{TiO}_{2}$ film (solid line) and in acetonitrile solution (dash line).

Inefficient energy conversion of solar cells (vide infra) using Ru-1 and Ru-2 may be due to absence of absorbance beyond $600 \mathrm{~nm}$. The absorption spectra and oxidation potentials of the Ru-12 and Ru-22 with phenyl acetate anchor are almost the same as $\mathrm{Ru}-1$ and $\mathrm{Ru}-2$, respectively.

\subsection{Working principle of the $\mathrm{TiO}_{2} \mathrm{DSSCS}$}

According to the spectroscopic and electrochemical measurements, the energy level of each Ru complex can be calculated and was shown in Fig. 4. 


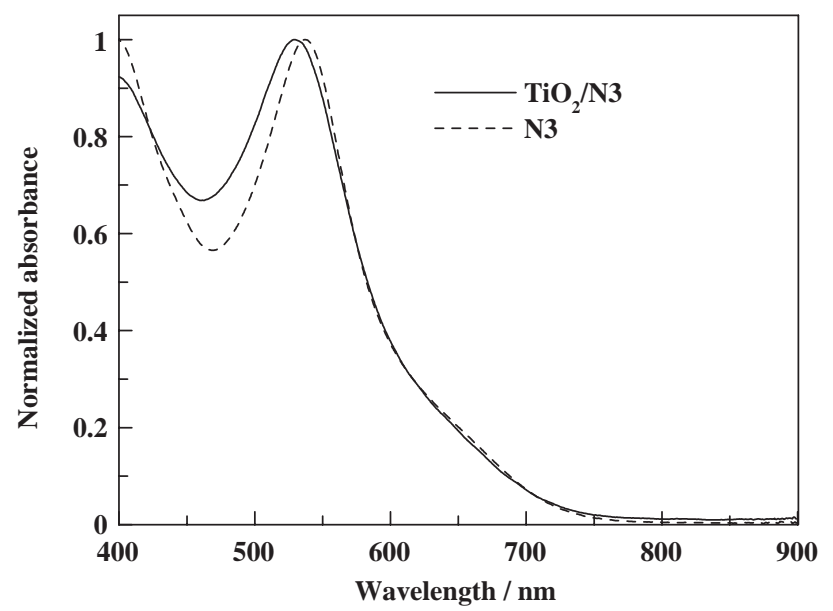

Fig. 3. Normalized absorption spectra of $\mathrm{N} 3$ on $\mathrm{TiO}_{2}$ film (solid line) and in ethanol solution (dash line).

Table 1

Absorption and electrochemical data of Ru complexes

\begin{tabular}{lllr}
\hline & \multicolumn{2}{c}{ Absorption } & \\
\cline { 2 - 3 } Complex & $\lambda_{\max } / \mathrm{nm}\left(\varepsilon / 10^{4} \mathrm{M}^{-1} \mathrm{~cm}^{-1}\right)$ & $E_{\text {ox }}^{0^{\prime} \mathrm{c}}(\mathrm{V})$ & $E_{\mathrm{red}}^{0^{\prime}}(\mathrm{V})$ \\
\hline Ru-1 & $507(0.55)^{\mathrm{a}}$ & 1.20 & -1.02 \\
Ru-12 & $507(1.12)^{\mathrm{a}}$ & 1.25 & -1.03 \\
Ru-2 & $460(0.64)^{\mathrm{b}}$ & 1.40 & -1.29 \\
Ru-22 & $460(1.60)^{\mathrm{b}}$ & 1.33 & -1.30 \\
N3 $^{\mathrm{d}}$ & $534(1.42)$ & 1.09 & - \\
\hline
\end{tabular}

${ }^{\mathrm{a}}$ Measured in DMF solution.

${ }^{\mathrm{b}}$ Measured in acetonitrile solution.

${ }^{\mathrm{c}} \mathrm{All} \mathrm{E}^{0 \prime}$ data are reported relative to NHE, which were calibrated from ferrocene $(0.55 \mathrm{~V}$ vs. NHE) in $\mathrm{CH}_{2} \mathrm{Cl}_{2}$ solution, The concentration of the complexes used in this experiment was $10^{-3} \mathrm{M}$ containing $0.1 \mathrm{M}$ TBAP (tetrabutylammonium hexafluorophosphate) in $\mathrm{CH}_{2} \mathrm{Cl}_{2}$ solution at 25 and the scan rate was $100 \mathrm{mV} \mathrm{s}^{-1}$.

${ }^{\mathrm{d}}$ Data from Ref. [4].

HOMO was calculated from $E_{\mathrm{ox}}^{0^{\prime}}$ in Table 1; while lowest unoccupied molecular orbital (LUMO) was obtained from the subtraction $E_{\mathrm{ox}}^{0^{\prime}}$ by energy gap estimated from electronic absorption edge. The transition energy of $\mathrm{Ru}-1$ or Ru-2 was shifted to higher energy than N3, indicating that TAPNB may be less efficient electron acceptor compared to the bipyridyl ligand in N3. The energy levels of Ru-1 are very similar to those of Ru-11, and so are $\mathrm{Ru}-2-\mathrm{Ru}-22$. It can be concluded here that elongation of the conjugation length 


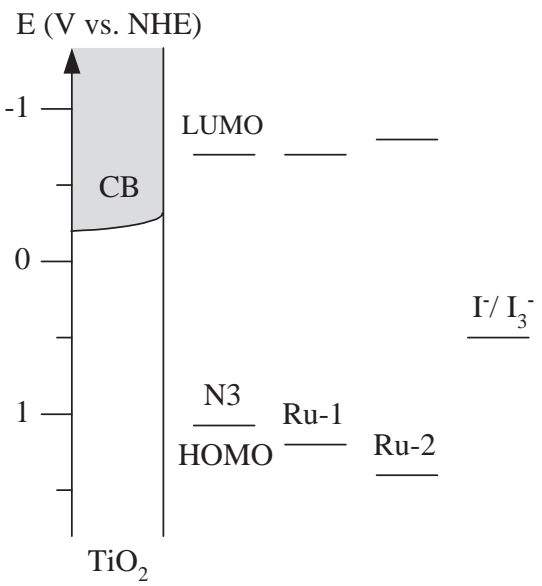

Fig. 4. Schematic illustration of the energy band diagram of $\mathrm{Ru}$ dyes, $\mathrm{TiO}_{2}$, and redox couple of iodide/tri iodide. This was constructed from spectroscopic and electrochemical measurements.

or pyridine ligand without electron-withdrawing would shift the ground state downward.

\subsection{Photocurrent-voltage characteristics}

Photocurrent-voltage ( $I-V$ ) characteristics of the DSSCs fabricated with Ru-1 and Ru-2 dyes were measured under illumination by a simulated AM 1.5 solar light. The $I-V$ curves of DSSCs with Ru-1 and Ru-2 complexes were shown in Fig. 5. The values of open-circuit voltage were similar, however, the short-circuit current of Ru2 was twice as large as that of $\mathrm{Ru}-1$. The low current density of Ru-1 was mainly caused by the small amount of dye adsorbed, measured and presented as $\Delta A$ in Table 2. This may be due to the greater steric hindrance of $\mathrm{Ru}-1$. The overall conversion efficiencies for DSSCs made with Ru-1, Ru-2, and N3 were $0.25 \%$, $0.79 \%$, and $4.54 \%$, respectively. The low efficiency and current density were partially caused by the small amount of dyes adsorbed, only ca. 1/4 (estimated from $\Delta A / \varepsilon_{\max }$ ) for $\mathrm{Ru}-1$ when compared with that of N3. Another reason may be due to lack of absorption beyond $\lambda>600 \mathrm{~nm}$. Energy gaps of both dyes are large, $1.9 \mathrm{eV}$ for $\mathrm{Ru}-1$ and $2.2 \mathrm{eV}$ for $\mathrm{Ru}-2$, as compared with $\mathrm{N} 3 \mathrm{of} 1.7 \mathrm{eV}$. It is inefficient in harvesting solar energy. Direct bonding between the titanium ion and the complex is not possible when benzoic acid anchor was replaced by phenyl acetate anchor (Ru-12 and $\mathrm{Ru}-22$ ). Instead, the interaction between the complex and $\mathrm{TiO}_{2}$ may involve the hydrogen bond with surface hydroxyl group of $\mathrm{TiO}_{2}$ or Van der Waals force adsorption. The weaker interaction will result in less amount of $\mathrm{Ru}-12$ (or Ru-22) adsorbed by $\mathrm{TiO}_{2}$ when compared to $\mathrm{Ru}-1$ (or $\mathrm{Ru}-2$ ). Less effective electronic coupling between $\mathrm{Ti} 3 \mathrm{~d}$ orbital and $\pi^{*}$ orbital on ligand will also lead to smaller photocurrents in Ru-12 (or Ru-22) than that of Ru-1 (or Ru-2). 


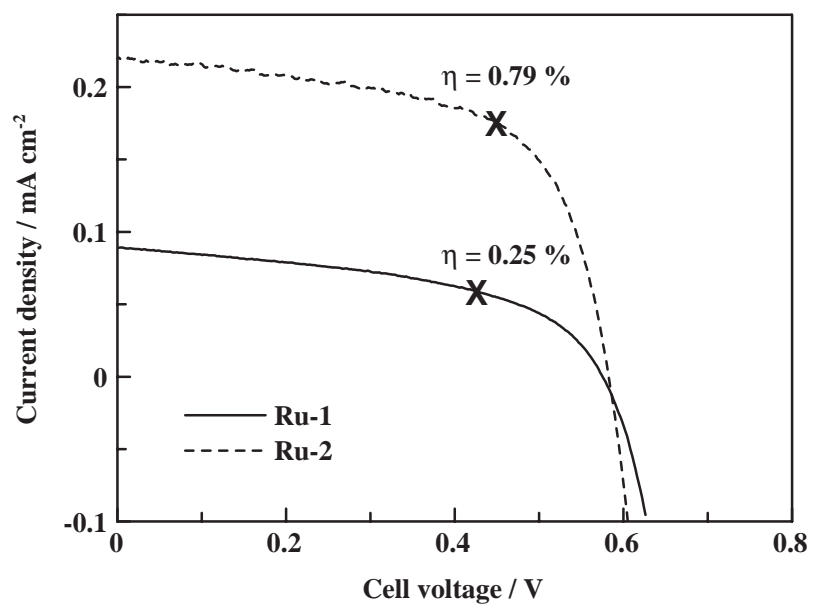

Fig. 5. Photocurrent-voltage characteristics of DSSCs with Ru-1 and Ru-2 complexes under illumination.

Table 2

Performance parameters of $\mathrm{TiO}_{2}$ solar cells sensitized with $\mathrm{Ru}$ complexes

\begin{tabular}{lllllll}
\hline Complex & $V_{\mathrm{oc}}(\mathrm{V})$ & $I_{\mathrm{sc}}\left(\mathrm{mAcm}^{-2}\right)$ & $\eta^{\mathrm{a}}(\%)$ & FF & IPCE $^{\mathrm{b}}(\%)$ & $\Delta A^{\mathrm{c}}$ \\
\hline Ru-1 & 0.57 & 0.09 & 0.25 & 0.49 & 11 & 0.29 \\
Ru-12 & 0.55 & 0.07 & 0.17 & 0.46 & - & 0.28 \\
Ru-2 & 0.58 & 0.22 & 0.79 & 0.62 & 18 & 1.92 \\
Ru-22 & 0.56 & 0.10 & 0.30 & 0.54 & - & 0.85 \\
N3 & 0.58 & 1.26 & 4.54 & 0.62 & 40 & 1.42
\end{tabular}

${ }^{\mathrm{a}}$ Efficiency of the test solar cells with simulated AM 1.5 solar light of $10 \mathrm{~mW} \mathrm{~cm}{ }^{-2}$.

${ }^{\mathrm{b}} \mathrm{IPCE} / \%=\frac{1240}{\lambda / \mathrm{nm}} \frac{I_{\mathrm{sc}} / \mathrm{mA} \mathrm{cm}^{-2}}{P_{\text {Light }} / \mathrm{mW} \mathrm{cm}^{-2}}$, where $\lambda=500 \mathrm{~nm}$ and $P_{\text {Llight }}=2.8 \mathrm{~mW} \mathrm{~cm}^{-2}$.

${ }^{\mathrm{c}}$ Absorbance difference of a $\mathrm{TiO}_{2}$ photoanode before and after adsorbed the complex at the maximum wavelength.

\section{Conclusions}

Two $\mathrm{Ru}$ complexes with phenanthrenyl ligand have been synthesized and their spectroscopic and electrochemical properties were studied. The compound with thiocyanate ancillary ligand absorbes at longer wavelength than that with bipyridine ancillary ligand. The larger steric congestion of the former results in less efficient adsorption by $\mathrm{TiO}_{2}$, however. The lower efficiency of the photovoltaic devices than that of $\mathrm{N} 3$ device is attributed to the absence of the absorption at longer wavelength and poorer adsorption by $\mathrm{TiO}_{2}$ in the former. When benzoic acid anchor was replaced by phenyl acetate anchor, the linkage between Ti $3 \mathrm{~d}$ orbital and $\pi^{*}$ orbital on ligand was even less effective, and smaller photocurrent was detected. Further modification of the phenanthrenyl ligand is in progress. 


\section{Acknowledgements}

The authors want to thank Pi-Tai Chou of the Department of Chemistry at the National Taiwan University for spectroscopic measurements. This work was financially supported through a grant from the CTCI Foundation, Taipei, Taiwan. Useful discussions with Dr. Jin-Guu Wang and Dr. Teh-Ming Tao, of the CTCI Foundation, are deeply appreciated.

\section{References}

[1] H. Meier, J. Phys. Chem. 69 (1965) 719.

[2] H. Tsubomura, M. Matsumura, Y. Nomura, T. Amamiya, Nature 261 (1976) 402.

[3] B. O'Regan, M. Grätzel, Nature 353 (1991) 737.

[4] M.K. Nazeeruddin, A. Kay, I. Rodicio, R. Humphry-Baker, E. Müller, P. Liska, N. Vlachopoulos, M. Grätzel, J. Am. Chem. Soc. 115 (1993) 6382.

[5] C.J. Barbé, F. Arendse, P. Comte, M. Jirousek, F. Lenzmann, V. Shklover, M. Grätzel, J. Am. Ceram. Soc. 80 (1997) 3157.

[6] Z.-S. Wang, F.-Y. Li, C.-H. Huang, Chem. Commun. (2000) 2063.

[7] K. Hara, M. Kurashige, S. Ito, A. Shinpo, S. Suga, K. Sayama, H. Arakawa, Chem. Commun. (2003) 252.

[8] K. Hara, M. Kurashige, Y. Dan-oh, C. Kasada, A. Shinpo, S. Suga, K. Sayama, H. Arakawa, New J. Chem. 27 (2003) 783.

[9] A. Dhanabalan, K.J. van Duren, P.A. van Hal, J.L.J. Dongen, R.A.J. Janssen, Adv. Funct. Mater. 11 (2001) 255.

[10] C.J. Brabec, C. Winder, N.S. Sacriciftic, J.C. Hummeden, A. Dhanabalan, P.A. van Hal, R.A.J. Janssen, Adv. Funct. Mater. 12 (2002) 709.

[11] A. Hagfeldt, M. Grätzel, Acc. Chem. Res. 33 (2000) 269.

[12] Md.K. Nazeeruddin, P. Péchy, T. Renouard, S.M. Zakeeruddin, R. Humphry-Baker, P. Comte, P. Liska, L. Cevey, E. Costa, V. Shklover, L. Spiccia, G.B. Deacon, C.A. Bignozzi, M. Grätzel, J. Am. Chem. Soc. 123 (2001) 1613.

[13] Z.-S. Wang, C.-H. Huang, Y.-Y. Huang, B.-W. Zhang, P.-H. Xie, Y.-J. Hou, K. Ibrahim, H.-J. Qian, F.-Q. Liu, Sol. Energy Mater. Sol. Cells 71 (2002) 261.

[14] Md.K. Nazeeruddin, R. Humphry-Baker, P. Liska, M. Grätzel, J. Phys. Chem. B 107 (2003) 8981.

[15] S. Ruile, O. Kohle, C. Klemenz, P. Péchy, M. Grätzel, Inorg. Chim. Acta 261 (1997) 129.

[16] A. Islam, H. Sugohara, H. Arakawa, J. Photochem. Photobiol. A: Chem 158 (2003) 131.

[17] M.K. Nazeeruddin, E. Müller, R. Humphry-Baker, N. Vlachopoulos, M. Grätzel, J. Chem. Soc. Dalton Trans. (1997) 4571.

[18] P.-T. Chou, Y.-C. Chen, W.-S. Yu, Y.-H. Chou, C.-Y. Wei, Y.-M. Cheng, J. Phys. Chem. A 105 (2001) 1731.

[19] K.R.J. Thomas, J.-T. Lin, H.-M. Lin, C.-P. Chang, C.-H. Chuen, Organometallics 20 (2001) 557.

[20] D.A. Gulino, H.G. Drickamer, J. Phys. Chem. 88 (1984) 1173. 